\title{
Dear members of the Korean Academy of Preventive Dentistry and Oral Health (KAPDOH)
}

Ja-Won Cho

Associate Editor of the KAPDOH

Hello. I am Ja-Won Cho, newly appointed Associate Editor of the KAPDOH.

2020 has been a whirlwind of a year due to the outbreak of coronavirus 2019.

First of all, I would like to express my special thanks to Bo-hyoung Jin, the former editing director, who invested great time and effort to the Journal of Korean Academy of Oral Health (JKAOH), the official journal of the KAPDOH, and to ensuring its registration in the Korean Citation Index of the National Research Foundation of Korea. I would also like to express my gratitude to all the editors, who have worked to maintain the respected status of JKAOH and devoted more attention to the research papers submitted to our journal than to their own research.

As an increasing number of academic journals have begun to compete with the JKAOH, the proportion of research papers submitted to our journal has decreased. Under these circumstances, it would be truly appreciated if the members of the KAPDOH give greater consideration to our journal and do us the honor of submitting your research papers to it.

Furthermore, I hope that we can move forward with a fresh outlook to constantly advance JKAOH in the upcoming year.

I wish you all a Happy New Year!

Thank you so much.

Best regards,

December 2020 


\section{대한예방치과·구강보건학회 회원 여러분께}

조자원

편집이사

안녕하십니까.

대한예방치과·구강보건학회 회원여러분.

올해부터 새로이 학회 편집이사를 맡은 조자원입니다.

코로나로 인해 정신없이 지나간 2020년 한 해가 지나가고 있습니다.

우선 우리 학회의 공식 저널인 "대한구강보건학회지”를 한국연구재단 등재지로 계속 유지될 수 있도록 많은 노력과 시간을 들여주신 전임 진 보형 이사님에게 특별한 감사를 드립니다. 또한, 본인들의 논문보다 투고된 논문에 더 많은 관심을 기울이고 현재의 학회지를 유지하는 데 도움을 주신 모든 편집 위원들께도 감사드립니다.

현재 많은 경쟁 학회지들이 늘어나고 있어, 본 학회지에 대한 투고율이 줄어들고 있는 상태입니다. 대한구강보건학회지의 유지와 발전을 위 해 학회의 모든 구성원이 대한구강보건학회지에 더욱 관심을 가져주시기를 부탁드리며, 좋은 논문을 투고해주시기를 바랍니다.

우리 모두가 새로운 마음으로 대한구강보건학회지의 끝없는 발전을 위해 한 걸음 한 걸음 앞으로 나아가야 할 것입니다.

새해 복 많이 받으세요!

감사합니다.

2020. 12 . 